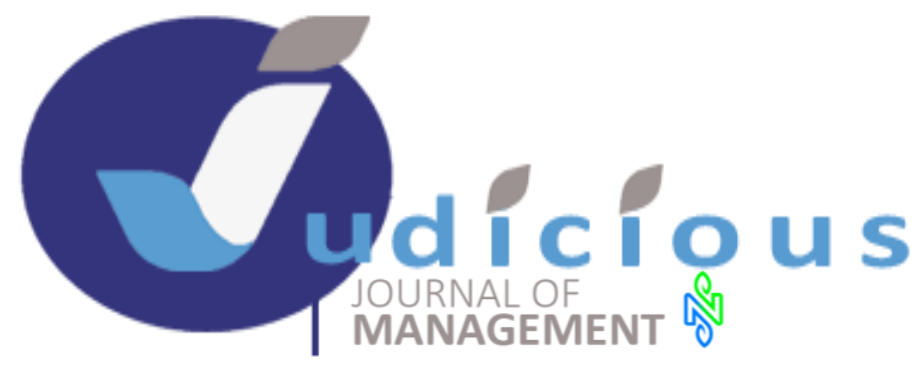

\title{
ANALISIS BELANJA PEGAWAI DAN BELANJA OPERASIONAL DALAM MENINGKATKAN KINERJA KEUANGAN DPRD KABUPATEN KONAWE UTARA
}

\author{
Suman Anselah \\ Fakultas Ekonomi dan Bisnis Islam \\ IAIN Kendari
}

\begin{abstract}
Abstrak
Penelitian ini bertujuan untuk menganalisis dan menjelaskan pengaruh Belanja Pegawai dan Belanja Operasional secara simultan terhadap Kinerja Keuangan, dan pengaruh Belanja Pegawai terhadap Kinerja Keuangan, kemudian pengaruh Belanja Operasional terhadap Kinerja Keuangan Kabupaten Konawe Utara. Metode analisis yang digunakan adalah korelasi, untuk mengetahui hubungan variabel belanja pegawai (X1) dan belanja operasional (X2) dengan kinerja keuangan (Y), kemudian untuk menguji hipotesis menggunakan analisis Regresi linear berganda, dengan menggunakan data laporan keuangan realisasi tahun anggaran 2014-2017 Kabupaten Konawe Utara, serta Informasi kualitatif digunakan untuk menggali tambahan informasi berkaitan dengan hasil pengujian hipotesis. Hasil penelitian ini menunjukkan bahwa: terdapat pengaruh yang signifikan antara belanja pegawai dengan kinerja keuangan dan belanja operasional terhadap kinerja keuangan, serta Belanja pegawai dan belanja operasional secara simultan atau bersama-sama berpengaruh terhadap kinerja keuangan, artinya peningkatan belanja pegawai dan belanja operasional akan berdampak pada peningkatan kualitas kinerja keuangan Kabupaten Konawe Utara.

Kata kunci: belanja pegawai, belanja operasional dan kinerja keuangan

*) Corresponding Author: suman_ansella@yahoo.com
\end{abstract}

\section{PENDAHULUAN}

Paradigma pengelolaan keuangan daerah telah mengalami perubahan yang sangat mendasar sejak diterapkannya otonomi daerah yaitu Undang-Undang Nomor 32 Tahun 2004 tentang Pemerintah Daerah dan Undang-Undang Nomor 33 Tahun 2004 tentang Perimbangan Keuangan antara Pemerintah Pusat dan Daerah, maka kekuasaan atau tanggung jawab yang dibebankan kepada pemerintah daerah untuk mengelola daerahnya secara maksimal menjadi lebih besar. Hal ini ditujukan agar distribusi dan pemanfaatan sumber daya alam nasional dapat merata dan terciptanya keseimbangan keuangan antara pemerintah daerah dan pemerintah pusat. Berlakunya Undang-Undang tentang Otonomi Daerah serta Pengelolaan dan Pertanggungjawaban Pengawasan Keuangan Daerah tersebut juga memberikan dampak positif bagi kedudukan, fungsi dan hak-hak Kabupaten/kota, di mana Kabupaten/kota yang merupakan perpanjangan tangan pemerintah pusat. Selain itu, adanya otonomi daerah merupakan tuntutan bagi pemerintah daerah dalam menciptakan good governance yaitu dengan mengutamakan akuntabilitas dan transparansi dalam pelaksanaan tata kelola pemerintahan.

Tata kelola pemerintahan yang baik merupakan cerminan pemerintahan yang akuntabilitas dan transparansi dalam menciptakan good governance yang baik selain tata kelola pemerintah sistem pengelolaan keuangan daerah yang baik akan berpengaruh terhadap kemajuan suatu daerah pula. Pengelolaan keuangan daerah yang dilakukan secara ekonomis, efisien, dan efektif atau memenuhi prinsip value for money serta partisipasi, transparansi, akuntabilitas dan keadilan akan dapat mendorong pertumbuhan ekonomi yang dapat dilihat dari kinerja keuangan daerah yang diukur menggunakan analisis rasio keuangan pemerintah daerah. Pengukuran kinerja keuangan pada pemerintah daerah juga digunakan untuk menilai akuntabilitas dan kemampuan keuangan daerah dalam penyelenggaraan otonomi daerah. Dengan demikian maka suatu daerah yang kinerja keuangannya dinyatakan baik berarti daerah tersebut memiliki kemampuan keuangan untuk membiayai pelaksanaan otonomi daerah. 
Kinerja keuangan adalah suatu ukuran kinerja yang menggunakan indikator keuangan. Analisis kinerja keuangan pada dasarnya dilakukan untuk menilai kinerja di masa lalu dengan melakukan berbagai analisis sehingga diperoleh posisi keuangan yang mewakili realitas entitas dan potensi-potensi kinerja yang akan berlanjut. Analisis keuangan adalah usaha mengidentifikasi ciri-ciri keuangan berdasarkan laporan keuangan yang tersedia (Abdul, 2008). Dalam organisasi pemerintah untuk mengukur kinerja keuangan ada beberapa ukuran kinerja, yaitu derajat desentralisasi, ketergantungan keuangan, rasio kemandirian keuangan daerah, rasio efektivitas, rasio efisiensi, rasio keserasian, dan pertumbuhan (Restianto, 2011).

Berdasarkan penjelasan tersebut menunjukkan bahwa salah satu aspek penting dalam rangka pelaksanaan kegiatan di Kabupaten Konawe Utara adalah masalah keuangan yang digunakan meliputi penggunaan anggaran belanja pegawai dan belanja operasional yang merupakan salah satu indikator penyerapan penggunaan anggaran yang terdapat pada Kabupaten Konawe Utara dalam mempertahankan dan meningkatkan keberhasilannya yang telah dicapai dari satu periode ke periode berikutnya. Untuk mengetahui peningkatan penyerapan anggaran dapat dilakukan analisis keuangan terlebih, sehingga dapat diketahui kinerja kabupaten tersebut apakah baik atau buruk yang dapat dilihat pada realisasi anggaran belanja modal dan belanja pegawai. Dalam penelitian dapat dilihat laporan pertumbuhan anggaran pendapatan dan belanja daerah (APBD) Kabupaten Konawe Utara Tahun anggaran 2010-2015 sebagai berikut ini:

Tabel 1. Pertumbuhan APBD (Pendapatan dan Belanja)

\begin{tabular}{clrc}
\hline Tahun & \multicolumn{1}{c}{ APBD } & Realisasi & $\begin{array}{c}\text { Pertumbuhan } \\
(\mathbf{\%})\end{array}$ \\
\hline 2011 & $1,086,511,159,933$ & $810,270,402,669$ & - \\
2012 & $1,037,978,094,050$ & $894,543,584,935$ & 9.42 \\
2013 & $1,169,329,243,942$ & $1,107,845,694,498$ & 19.25 \\
2014 & $1,537,062,786,910$ & $1,208,499,172,568$ & 8.33 \\
2015 & $1,537,062,786,910$ & $1,389,882,380,938$ & 13.05 \\
\hline Total & $6,367,944,071,745$ & $5,411,041,235,609$ & 50.05 \\
Rata-rata & $\mathbf{1 , 0 6 1 , 3 2 4 , 0 1 1 , 9 5 8}$ & $\mathbf{9 0 1 , 8 4 0 , 2 0 5 , 9 3 5}$ & $\mathbf{1 0 . 0 1}$ \\
\hline
\end{tabular}

Sumber : LPKD Kab. Konawe Utara 2011-2015 (Diolah)

Berdasarkan data pada tabel di atas menunjukkan bahwa tingkat pertumbuhan APBD Kabupaten Konawe Utara selama periode 2011-2015 cenderung fluktuasi, namun jika dilihat dari nominal APBD kabupaten Konawe Utara mengalami peningkatan dari tahun ke tahun dengan rata-rata pertumbuhan sebesar 10,01persen per tahunnya. Dari data tersebut memberikan gambaran adanya peningkatan pada tahun 2013 dengan peningkatan sebesar 19,25 persen. Hal ini terjadi seiring dengan waktu dan diberlakukannya otonomi daerah di setiap Kabupaten/Kota di Indonesia yang memperoleh alokasi dana perimbangan. Selanjutnya pertumbuhan kedua terjadi pada tahun 2015 sebesar 13,05 persen. Fenomena tersebut tentunya berimplikasi pada peningkatan kinerja keuangan Kabupaten Konawe Utara sebagai perpanjangan pemerintahan pusat.

Fenomena di lapangan menunjukkan bahwa kinerja keuangan DPRD kabupaten Konawe Utara dalam realisasi anggaran masih tergolong rendah dalam penyerapannya, hal disebabkan daerah otonom Konawe Utara masih tergolong baru, sehingga penyerapan anggaran masih kurang optimal dalam pelaksanaannya, selain itu tingginya ketergantungan Pemda pada Pemerintah Pusat, hal tersebut menjadi masalah tersendiri dalam peningkatan kinerja yang berbasis pada opini pengelolaan keuangan wajar tanpa pengecualian (WTP).

Banyak penelitian mengenai Kinerja Keuangan daerah di berbagai tempat, namun memberikan hasil yang berbeda-beda. Oleh karena itu, penelitian ini dengan tujuan untuk menganalisis dan menjelaskan pengaruh Belanja Pegawai dan Belanja Operasional terhadap Kinerja Keuangan di Kabupaten Konawe Utara. 


\section{Kinerja Keuangan Pemerintah Daerah}

Kinerja merupakan pencapaian atas apa yang direncanakan, apabila pencapaian sesuai dengan yang direncanakan, maka kinerja yang dilakukan terlaksana dengan baik. Untuk menilai kinerja digunakan ukuran penilaian berdasarkan indikator sebagai berikut: a) Masukan (input) adalah tolak ukur kinerja berdasarkan besaran sumber dana yang digunakan untuk melaksanakan program atau kegiatan; b) Keluaran (output) adalah tolak ukur kinerja berdasarkan produk (barang atau jasa) yang dihasilkan dari program atau kegiatan sesuai dengan masukan yang digunakan; c) Hasil (outcame) adalah tolak ukur kinerja berdasarkan tingkat keberhasilan yang dicapai berdasarkan tingkat keluaran program atau kegiatan yang sudah dilaksanakan.

Konsep pengelolaan organisasi sektor publik yang mendasar pada elemen utama, yaitu: ekonomi, efisiensi dan efektivitas. Sedangkan, dalam pengukuran kinerja menggunakan ukuran efisiensi. Efisiensi adalah pencapaian output yang maksimum dengan input tertentu atau penggunaan input yang terendah untuk mencapai output tertentu. Semakin besar output dibanding input, maka semakin tinggi tingkat efisiensi suatu organisasi, maka proksi pengukuran kinerja pemerintah daerah untuk kabupaten dan kota digunakan dengan rumus efisiensi dan diukur dengan rasio output dengan input (Mardiasmo, 2009). Input adalah sumber daya yang digunakan untuk pelaksanaan suatu kebijakan, program dan aktivitas. Sedangkan, output adalah hasil yang dicapai dari suatu program, aktivitas, dan kebijakan. penyebut atau input sekunder sering kali diukur dalam bentuk satuan uang. Pembilang atau output dapat diukur baik dalam jumlah uang ataupun fisik (Mardiasmo, 2009). Rasio Efisiensi, Kinerja merupakan gambaran pencapaian pelaksanaan suatu kegiatan dalam mencapai tujuan, visi dan misi suatu organisasi (Bastian, 2006). Alokasi biaya ditransformasikan ke rasio efisiensi yaitu: Perhitungan rasio efisiensi terhadap kinerja keuangan sebagai berikut: Efisiensi $=(($ Realisasi Pengeluaran $) /($ Realisasi Penerimaan $)) \times 100 \%$

\section{Anggaran Pendapatan Dan Belanja Daerah}

Anggaran Pendapatan dan Belanja Daerah selanjutnya disingkat APBD adalah suatu rencana keuangan tahunan pemerintah daerah yang disetujui oleh Dewan Perwakilan Rakyat Daerah (UU No. 17 Tahun 2003 pasal 1 butir 8 tentang Keuangan Negara). Semua Penerimaan Daerah dan Pengeluaran Daerah harus dicatat dan dikelola dalam APBD. Penerimaan dan pengeluaran daerah tersebut adalah dalam rangka pelaksanaan tugas-tugas desentralisasi. Sedangkan penerimaan dan pengeluaran yang berkaitan dengan pelaksanaan Dekonsentrasi atau Tugas Pembantuan tidak dicatat dalam APBD.

APBD merupakan dasar pengelolaan keuangan daerah dalam satu tahun anggaran. APBD merupakan rencana pelaksanaan semua Pendapatan Daerah dan semua Belanja Daerah dalam rangka pelaksanaan desentralisasi dalam tahun anggaran tertentu. Pemungutan semua penerimaan daerah bertujuan untuk memenuhi target yang ditetapkan dalam APBD. Demikian pula semua pengeluaran daerah dan ikatan yang membebani daerah dalam rangka pelaksanaan desentralisasi dilakukan sesuai jumlah dan sasaran yang ditetapkan dalam APBD. Karena APBD merupakan dasar pengelolaan keuangan daerah, maka APBD menjadi dasar pula bagi kegiatan pengendalian, pemeriksaan dan pengawasan keuangan daerah.

Tahun anggaran APBD sama dengan tahun anggaran APBN yaitu mulai 1 Januari dan berakhir tanggal 31 Desember tahun yang bersangkutan. Sehingga pengelolaan, pengendalian, dan pengawasan keuangan daerah dapat dilaksanakan berdasarkan kerangka waktu tersebut.

\section{Belanja Modal}

Belanja daerah dikelompokkan menjadi belanja langsung dan tidak langsung. Biaya langsung terdiri dari belanja pegawai, belanja barang dan jasa serta belanja modal. Menurut Permendagri No. 13 Tahun 2006 Pasal 53 Belanja Modal digunakan untuk pengeluaran yang dilakukan dalam rangka pembelian/pengadaan atau pembangunan aset tetap berwujud yang mempunyai nilai manfaat lebih dari 12 bulan untuk digunakan dalam kegiatan pemerintahan, seperti dalam bentuk tanah, peralatan dan mesin, gedung dan bangunan, jalan, irigasi dan jaringan, dan aset tetap lainnya .

Peningkatan kualitas pelayanan publik dapat diperbaiki melalui perbaikan manajemen kualitas jasa (service quality management), yakni upaya meminimalisasi kesenjangan (gap) antara tingkat layanan dengan harapan konsumen (Bastian, 2006). Dengan demikian, pemerintah daerah harus mampu mengalokasikan alokasi belanja modal dengan baik karena belanja modal merupakan salah satu langkah bagi pemerintah daerah untuk memberikan pelayanan kepada publik. 
Belanja Modal digunakan untuk memperoleh keuntungan pada masa yang akan datang sesuai dengan masa manfaat ekonomis aktiva yang bersangkutan. Oleh sebab itu, perhitungan antara biaya yang dikeluarkan dan manfaat yang akan diperoleh harus dapat diperbandingkan.

\section{METODE}

Dalam penelitian ini, Metode pengumpulan data pada penelitian ini adalah dengan mengumpulkan data sekunder, yaitu laporan realisasi tahun anggaran 2014-2017 DPRD Kabupaten Konawe Utara. Ada tiga variabel yang digunakan yaitu: Kinerja Keuangan DPRD sebagai dependent variable, sedangkan Belanja Pegawai dan Belanja Operasional sebagai independent variable.

Analisis statistik yang digunakan adalah dengan menggunakan analisis regresi linear berganda. Dalam analisis agar penjabaran hasil penelitian lebih jelas dan mendalam selain digunakan metode kuantitatif juga digunakan metode kualitatif. Uji statistik regresi linier berganda dikatakan model yang baik jika model tersebut memenuhi asumsi normalitas data dan terbebas dari asumsi-asumsi klasik statistik, baik auto korelasi, heteroskesdastisitas dan multikolineritas. Model persamaannya sebagai berikut:

$$
Y=\alpha+\beta 1 X^{1}+\beta 2 X^{2}+e
$$

Di mana:

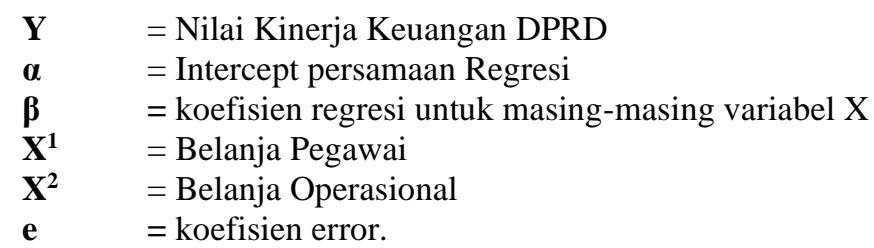

\section{HASIL DAN PEMBAHASAN}

\section{Hasil}

Belanja Pegawai

Belanja pegawai dalam penelitian ini diukur dengan indikator Belanja pegawai langsung dan Belanja pegawai tidak langsung. Perkembangan Belanja pegawai langsung dan Belanja pegawai tidak langsung pada sekretariat DPRD Kabupaten Konawe Utara dari tahun 2015-2017, dapat dilihat pada tabel 2 berikut:

Tabel 2. Perkembangan rata-rata indikator variabel Belanja pegawai.

\begin{tabular}{|c|c|c|c|c|c|c|c|c|}
\hline Indikator & & 2014 & 2015 & 2016 & 2017 & Maximal & Minimal & Rata-rata \\
\hline \multirow{4}{*}{ X1.1 $\begin{array}{l}\text { Belanja pegawai } \\
\text { langsung }\end{array}$} & I & $11,407,257.89$ & $22,814,515.78$ & $15,209,677.18$ & $18,720,572.74$ & $22,814,516$ & $11,407,258$ & $17,038,006$ \\
\hline & $\|$ & $26,616,935.07$ & $53,233,870.14$ & $35,489,246.76$ & $43,681,336.40$ & $53,233,870$ & $26,616,935$ & $39,755,347$ \\
\hline & III & $38,024,192.96$ & $76,048,385.92$ & $50,698,923.95$ & $62,401,909.14$ & $76,048,386$ & $38,024,193$ & $56,793,353$ \\
\hline & IV & $114,072,578.88$ & $228,145,157.76$ & $152,096,771.84$ & $187,205,727.41$ & $228,145,158$ & $114,072,579$ & $170,380,059$ \\
\hline \multirow{5}{*}{$\begin{array}{l}\text { X1.2 } \begin{array}{l}\text { Belanja pegwai } \\
\text { tidak langsung }\end{array}\end{array}$} & & $47,530,241.20$ & $95,060,482.40$ & $63,373,654.93$ & $78,002,386.42$ & $95,060,482$ & $47,530,241$ & $70,991,691$ \\
\hline & I & $37,631,257.83$ & $75,262,515.66$ & $50,175,010.44$ & $61,757,059.10$ & $75,262,516$ & $37,631,258$ & $56,206,461$ \\
\hline & $\|$ & $87,806,268.27$ & $175,612,536.54$ & $117,075,024.36$ & $144,099,804.56$ & $175,612,537$ & $87,806,268$ & $131,148,408$ \\
\hline & III & $125,437,526.10$ & $250,875,052.20$ & $167,250,034.80$ & $205,856,863.66$ & $250,875,052$ & $125,437,526$ & $187,354,869$ \\
\hline & IV & $376,312,578.30$ & $752,625,156.61$ & $501,750,104.40$ & $617,570,590.99$ & $752,625,157$ & $376,312,578$ & $562,064,608$ \\
\hline Rata-rata (X1.1) & & $156,796,907.63$ & $313,593,815.25$ & $209,062,543.50$ & $257,321,079.58$ & $313,593,815$ & $156,796,908$ & $234,193,586$ \\
\hline
\end{tabular}

Sumber: Diolah (2020) 
Kondisi Belanja pegawai langsung pada tahun 2014-2017, pada tabel 2, rata-rata mencapai Rp70.991.691 dengan nilai rata-rata maksimal Rp95.060.482 dan nilai rata-rata minimal sebesar Rp47.530.241. Hal ini berarti bahwa selama kurun waktu tiga tahun dapat dilihat pada penggunaan anggaran Belanja pegawai langsung pada kabupaten Konawe Utara. Tertinggi terjadi pada tahun 2015 yang rata-rata mencapai Rp95.060.482,40 dan keyakinan terendah terjadi pada tahun 2014 yang hanya Rp47.530.241,20.

\section{Belanja Operasional}

Belanja operasional dalam penelitian ini diukur dengan tiga indikator yakni Belanja Barang dan Jasa, Belanja Perjalanan Dinas dan Belanja Pemeliharaan. Adapun perkembangan indikator tersebut dapat dilihat pada tabel 3 berikut:

Tabel 3. Perkembangan rata-rata indikator variabel Belanja Operasional

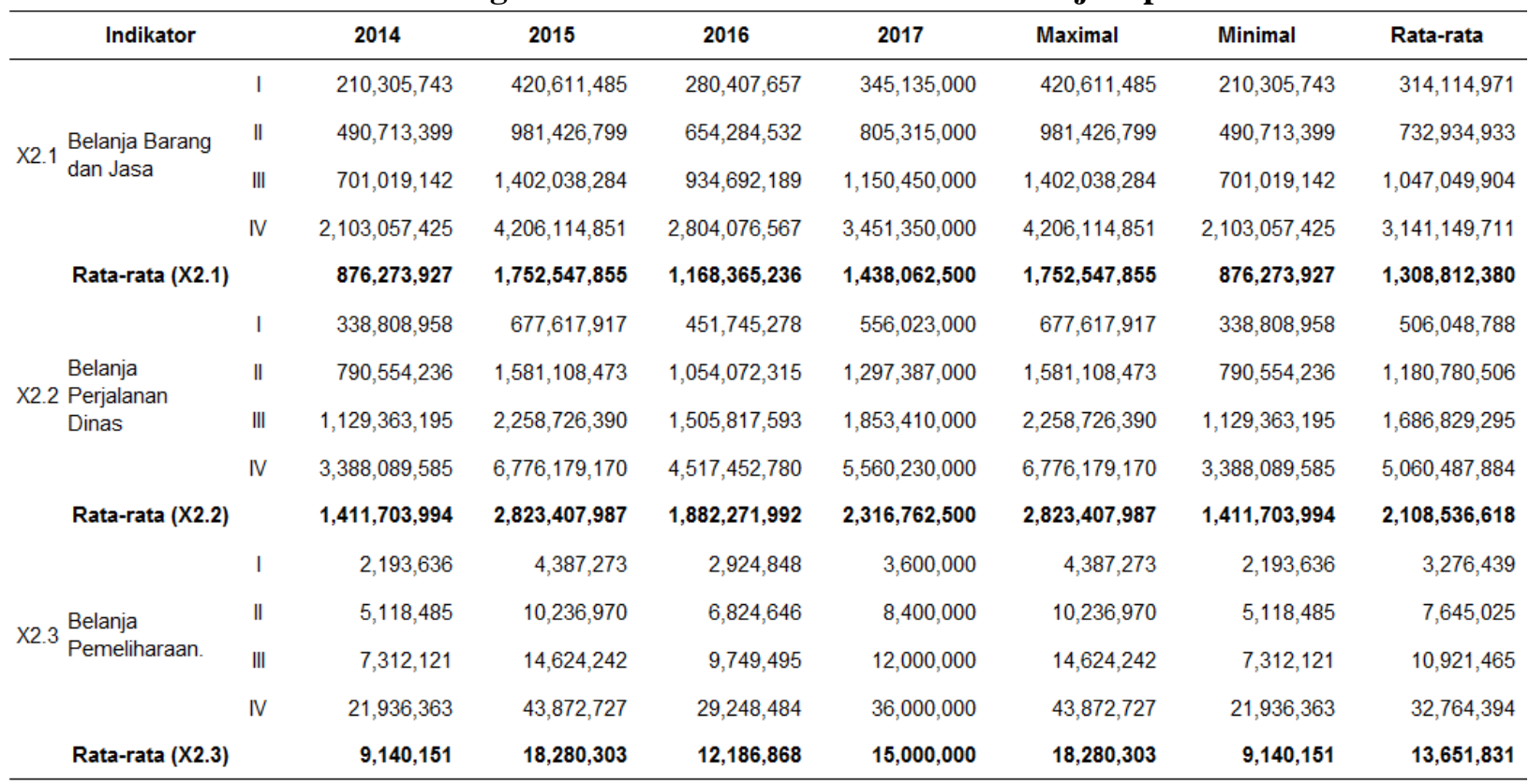

Sumber: Diolah (2020)

Berdasarkan pada tabel 3, di atas kondisi belanja barang dan jasa pada tahun 2014-2017, ratarata mencapai $\mathrm{Rp} 1.308 .812 .380$ dengan nilai rata-rata maksimal $\mathrm{Rp} 1.752 .547 .855$ dan nilai rata-rata minimal Rp876.273.927. Hal ini berarti bahwa selama kurun waktu tiga tahun dapat dilihat pada penggunaan anggaran belanja barang dan jasa pada kabupaten Konawe Utara. penggunaan anggaran belanja barang dan jasa tertinggi terjadi pada tahun 2015 yang rata-rata mencapai Rp1.752.547.855 dan keyakinan terendah terjadi pada tahun 2014 yang hanya Rp876.273.927.

Kemudian kondisi belanja perjalanan dinas selama kurun waktu 2014-2017 rata-rata mencapai Rp2.108.536.618 dengan nilai rata-rata maksimal Rp2.823.407.987 dan nilai minimal Rp1.411.703.994. Hal ini berarti bahwa selama kurun tiga tahun sekretariat DPRD Kabupaten Konawe Utara tinggi dalam tingkat keyakinannya. Hal ini dapat dilihat pada penggunaan anggaran belanja perjalanan dinas yang tertinggi terjadi pada tahun 2015 yang rata-rata mencapai Rp2.823.407.987 dan penggunaan anggaran perjalanan dinas yang dimiliki sekretariat DPRD Kabupaten Konawe Utara terendah terjadi pada tahun 2014 dengan tingkat kemampuan hanya Rp1.411.703.994.

\section{Kinerja Keuangan}

Kinerja Keuangan dalam penelitian ini diukur dengan menggunakan rasio perbandingan antara Realisasi Pengeluaran DPRD dengan Realisasi Penerimaan DPRD. Adapun perkembangan indikator tersebut dapat dilihat pada tabel 4 berikut: 
Tabel 4. Perkembangan Rata-Rata Indikator Variabel Kinerja Keuangan.

\begin{tabular}{clccccccc}
\hline No. & Indikator & $\mathbf{2 0 1 4}$ & $\mathbf{2 0 1 5}$ & $\mathbf{2 0 1 6}$ & $\mathbf{2 0 1 7}$ & Maximal & Minimal & Rata-rata \\
\hline 1 & Realisasi Pengeluaran & $17,154,707,210$ & $34,670,566,150$ & $12,857,001,614$ & $15,447,901,505$ & $34,670,566,150$ & $12,857,001,614$ & $20,032,544,120$ \\
& DPRD & & & & & & & \\
2 & $\begin{array}{l}\text { Realisasi Penerimaan } \\
\text { DPRD }\end{array}$ & $18,057,586,537$ & $36,115,173,073$ & $14,446,069,229$ & $17,780,698,864$ & $36,115,173,073$ & $14,446,069,229$ & $21,599,881,926$ \\
& Rasio Efisiensi & $\mathbf{0 . 9 5}$ & $\mathbf{0 . 9 6}$ & $\mathbf{0 . 8 9}$ & $\mathbf{0 . 8 7}$ & $\mathbf{0 . 9 6}$ & $\mathbf{0 . 8 7}$ & $\mathbf{0 . 9 2}$ \\
\hline
\end{tabular}

Sumber: Diolah (2020)

Kondisi rasio efisiensi pada tahun 2014-2017, pada tabel 4, rata-rata mencapai 0,92\% dengan nilai maksimal $0,96 \%$ dan nilai minimal $0,87 \%$. Hal ini berarti bahwa selama kurun waktu tiga tahun telah terjadi peningkatan kinerja keuangan dari tahun ke tahun pada sekretariat DPRD Kabupaten Konawe Utara. Kinerja keuangan dalam hal efisiensi penggunaan anggaran yang tinggi terjadi pada tahun 2015 yang rata-rata mencapai 0,96\% dan efisiensi penggunaan anggaran terendah terjadi pada tahun 2017 yang hanya 0,87\%. Dengan demikian Kinerja keuangan memberikan gambaran kondisi keuangan sekretariat DPRD Kabupaten Konawe Utara pada suatu periode tertentu menyangkut aspek penghimpunan dana maupun penyaluran dana, yang biasanya diukur dengan indikator rasio efisiensi.

\section{Analisa Deskriptif Statistik}

Statistik deskripsi di bawah ini menunjukkan bahwa variabel belanja pegawai memiliki standar deviasi tertinggi yakni 0,82 dengan mean 0,75 , kemudian variabel belanja operasional memiliki standar deviasi 0,61, selanjutnya variabel kinerja keuangan memiliki standar deviasi 0,56 dengan mean 1,22. Secara ringkas hasil pengujian deskripsi statistik variabel dapat dilihat pada tabel berikut ini:

Tabel 5 Statistik Deskriptif Variabel Penelitian Descriptive Statistics

\begin{tabular}{|c|c|c|c|c|c|}
\hline & $\mathrm{N}$ & Minimum & Maximum & Mean & Std. Deviation \\
\hline $\mathrm{X} 1$ & 16 & -1.20 & 1.80 & .7500 & .81731 \\
\hline $\mathrm{X} 2$ & 16 & -.50 & 1.70 & .7750 & 60937 \\
\hline $\mathrm{Y}$ & 16 & -.10 & 1.80 & 1.2188 & .56002 \\
\hline Valid N (listwise) & 16 & & & & \\
\hline
\end{tabular}

\section{Pengujian Hipotesis}

Untuk mengetahui pengaruh masing-masing variabel dengan menggunakan analisis regresi linear berganda melalui bantuan program SPSS 20.0 for Windows, dapat dilihat hasil pengolahan data pada rekapitulasi hasil analisis sebagai berikut:

Tabel 6. Hasil Analisis Regresi Pengaruh belanja pegawai $\left(\mathbf{X}_{1}\right)$, dan belanja operasional $\left(\mathbf{X}_{2}\right)$ Terhadap kinerja keuangan (Y)

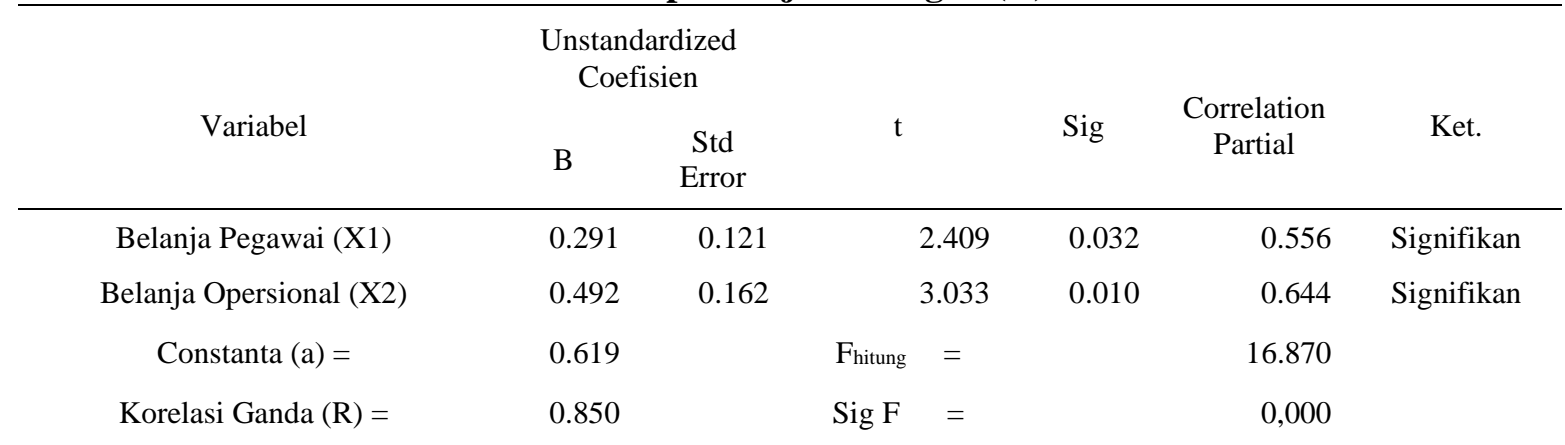




$\begin{array}{cccr}\begin{array}{c}\text { Koefisien determenasi ganda }(\mathrm{R} \\ \text { square })=\end{array} & 0.722 & \mathrm{~F}_{\text {tabel }}= & 3.806 \\ \text { Adjusted Square }= & 0.679 & \mathrm{~T}_{\text {tabel }}= & 2.160 \\ \text { Durbin-Watson }= & 2.390 & \mathrm{SEE}= & 0.31726\end{array}$

Sumber: Diolah (2020)

Berdasarkan hasil rekapitulasi di atas, maka untuk mengetahui hubungan dari masing-masing pengaruh antara belanja pegawai dan belanja operasional terhadap kinerja keuangan sekretariat DPRD Kabupaten Konawe Utara dapat dilihat pada Gambar berikut:

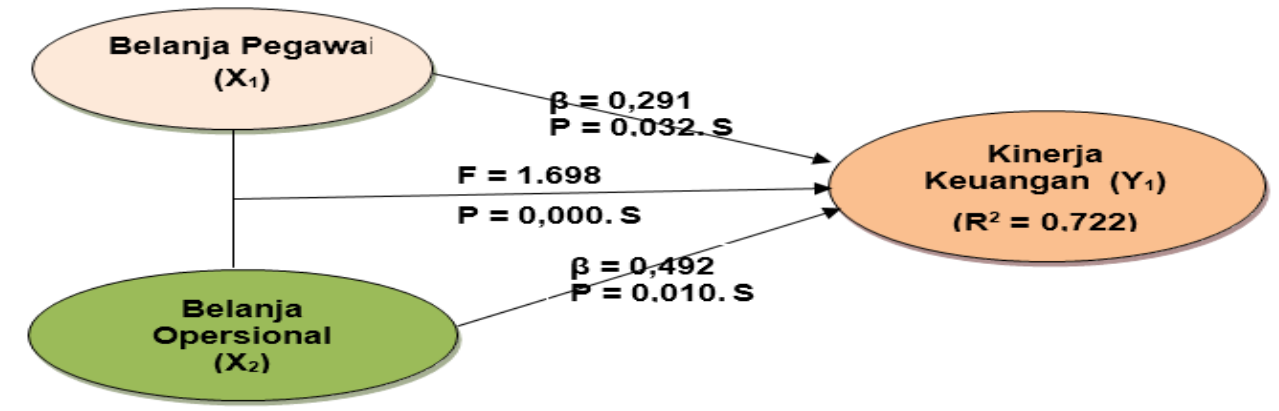

Keterangan :

Gambar 1. Hasil Pengujian Hipotesis

$\mathrm{S}=$ Jalur signifikan

TS = Jalur tidak signifikan

\section{Pembahasan}

Pengaruh belanja pegawai dan belanja operasional berpengaruh positif dan signifikan terhadap kinerja keuangan. Hal ini berarti bahwa dengan meningkatnya belanja pegawai dan belanja operasional maka akan meningkatkan kualitas kinerja keuangan pada Sekretariat DPRD Kabupaten Konawe Utara. Hal ini di perkuat pula melalui hasil analisis yang menunjukkan nilai koefisien korelasi sebesar 0,850 yang berarti bahwa belanja pegawai dan belanja operasional berpengaruh positif dan kuat terhadap kinerja keuangan. Adapun besarnya pengaruh perubahan belanja pegawai dan belanja operasional terhadap perubahan peningkatan kinerja keuangan ditunjukkan oleh nilai koefisien determinasi sebesar 0,722 yang berarti bahwa kinerja keuangan di pengaruhi oleh belanja pegawai dan belanja operasional di mana besar pengaruhnya adalah 72,20\% dengan asumsi faktor lain tetap.

Hasil penelitian ini sejalan dengan pendapat dari (Mardiasmo, 2009) yang menyatakan bahwa pengukuran kinerja menggunakan ukuran efisiensi yaitu pencapaian output yang maksimum dengan input tertentu atau penggunaan input yang terendah untuk mencapai output tertentu. Demikian pula dengan penelitian terdahulu menyatakan bahwa kinerja keuangan daerah tahun lalu berpengaruh signifikan terhadap alokasi belanja modal tahun berikutnya (Hidayat, 2013). Sehingga hipotesis awal terjawab bahwa semakin meningkat belanja pegawai dan belanja operasional, maka akan berdampak pada peningkatan kinerja keuangan DPDR Kabupaten Konawe Utara.

Belanja pegawai berpengaruh positif dan signifikan terhadap kinerja keuangan. Artinya bahwa peningkatan belanja pegawai maka akan berdampak pada peningkatan kinerja keuangan kantor Sekretariat DPRD Kabupaten Konawe Utara. Hasil ini menunjukkan belanja pegawai mampu menjelaskan variasi perubahan kinerja keuangan yang terdapat pada kantor kinerja keuangan kantor Sekretariat DPRD Kabupaten Konawe Utara, hal ini mengindikasikan belanja pegawai yang diterapkan pada kantor Sekretariat DPRD Kabupaten Konawe Utara mampu mendorong kinerja keuangan pegawai Sekretariat DPRD secara maksimal dengan output yang diharapkan. Hasil penelitian ini mendukung temuan dari penelitian terdahulu yang menyatakan bahwa belanja modal berpengaruh terhadap tingkat kemandirian keuangan daerah dan belanja pegawai berpengaruh terhadap tingkat kemandirian keuangan daerah (Darwis, 2015). Demikian juga dengan hasil penelitian yang lain menyatakan bahwa kinerja keuangan daerah tahun lalu berpengaruh signifikan terhadap alokasi belanja modal tahun 
berikutnya. Tingkat ketergantungan tahun lalu berpengaruh signifikan dengan arah negatif terhadap alokasi belanja modal tahun berikutnya (Hidayat, 2013).

Belanja operasional berpengaruh positif dan signifikan terhadap kinerja keuangan pada kantor Sekretariat DPRD Kabupaten Konawe Utara. Artinya bahwa apabila belanja operasional ditingkatkan maka akan berdampak pada peningkatan kinerja keuangan pada kantor Sekretariat DPRD Kabupaten Konawe Utara. Hasil ini menunjukkan belanja operasional mampu menjelaskan variasi perubahan yang terdapat pada kantor Sekretariat DPRD Kabupaten Konawe Utara, hal ini mengindikasikan penggunaan anggaran belanja operasional sesuai dengan aturan yang berlaku atau sesuai dengan undang-undang maka akan mampu mendorong pada peningkatan kinerja keuangan kantor Sekretariat DPRD Kabupaten Konawe Utara secara maksimal. Hasil penelitian ini mendukung temuan dari penelitian terdahulu yang menyatakan bahwa pemerintah daerah lebih mempertimbangkan di mana belanja yang di dalamnya mengenai kepentingan umum harus lebih ditingkatkan (Pinatik, 2016), demikian juga dengan penelitian yang lain menyatakan bahwa kompetensi aparatur pemerintah, penerapan akuntabilitas keuangan dan ketaatan pada peraturan perundangan berpengaruh terhadap akuntabilitas kinerja instansi terkait (Julita, 2011).

\section{PENUTUP}

Penelitian ini menganalisis dan menjelaskan pengaruh Belanja Pegawai dan Belanja Operasional secara simultan terhadap Kinerja Keuangan, dan pengaruh Belanja Pegawai terhadap Kinerja Keuangan, kemudian pengaruh Belanja Operasional terhadap Kinerja Keuangan Kabupaten Konawe Utara. Penelitian ini dilatarbelakangi oleh pentingnya Kinerja Keuangan suatu daerah. Selain itu, fenomena-fenomena dari berbagai hal yang juga turut mempengaruhi tinggi rendahnya Kinerja Keuangan. Hasil penelitian ini menunjukkan bahwa:

1. Belanja pegawai dan belanja operasional berpengaruh positif dan signifikan terhadap kinerja keuangan. Hasil penelitian ini bahwa dengan meningkatnya belanja pegawai dan belanja operasional maka akan meningkatkan kualitas kinerja keuangan Sekretariat DPRD Kabupaten Konawe Utara.

2. Belanja pegawai berpengaruh positif dan signifikan terhadap kinerja keuangan. Penelitian ini menunjukkan bahwa belanja pegawai yang tinggi akan berdampak pada peningkatan kinerja keuangan, dalam hal ini belanja pegawai mampu mendorong kinerja keuangan pegawai Sekretariat DPRD secara maksimal dengan output yang diharapkan.

Belanja operasional berpengaruh positif dan signifikan terhadap kinerja keuangan. Penelitian ini menunjukkan bahwa belanja operasional yang tinggi akan berdampak pada peningkatan kinerja keuangan, hal ini mengindikasikan penggunaan anggaran belanja operasional sesuai dengan aturan yang berlaku atau sesuai dengan undang-undang maka akan mampu mendorong pada peningkatan kinerja keuangan pada Sekretariat DPRD Kabupaten Konawe Utara secara maksimal.

\section{DAFTAR PUSTAKA}

Abdul, H. (2008). Auditing (Dasar-dasar Audit Laporan Keuangan). Yogyakarta: Unit Penerbit dan Percetakan STIM YKPN.

Bastian, I. (2006). Akuntansi sektor publik (Edisi 3). Erlangga. BPKP.

Darwis, E. T. R. (2015). Pengaruh Belanja Modal Dan Belanja Pegawai Terhadap Tingkat Kemandirian Keuangan Daerah Pada Kabupaten/Kota Provinsi Sumatera Barat (Studi Empiris Pada Kabupaten dan Kota Provinsi Sumatera Barat). Jurnal Ilmiah Fakultas Ekonomi Universitas Negeri Padang.

Hidayat, M. F. (2013). Analisis Pengaruh Kinerja Keuangan Daerah Terhadap Alokasi Belanja Modal (Studi pada Kabupaten dan Kota di Jawa Timur). Jurnal Jurusan Ilmu Ekonomi Fakultas Ekonomi Dan Bisnis Universitas Brawijaya Malang. 
Julita. (2011). Analisis Efektivitas dan Efisiensi Anggaran Pendapatan dan Belanja Pada Badan Lingkungan Hidup Provinsi Sumatera Utara. Kumpulan Jurnal Dosen Universitas Muhammadiyah Sumatera Utara, Vol 10(No 02).

Mardiasmo. (2009). Akuntansi Sektor Publik. Yogyakarta: Andi Offset.

Pinatik, F. X. . K. dan S. (2016). Analisis Kinerja Belanja pada Pemerintah Daerah Kabupaten Asmat Provinsi Papua. Jurnal EMBA, Vol.4(3), 572-582.

Restianto, H. S. dan Y. E. (2011). Pengaruh Kinerja Keuangan terhadap Alokasi Belanja Modal dan Pertumbuhan Ekonomi Kab/Kota Jawa Tengah. Jurnal Media Riset Akuntansi, Vol.1(2), hal 109-123.

Undang-Undang Nomor 17 Tahun 2003 tentang Keuangan Negara

Undang-Undang Nomor 32 Tahun 2004 tentang Pemerintah Daerah

Undang-Undang Nomor 33 Tahun 2004 tentang Perimbangan Keuangan antara Pemerintah Pusat dan Daerah 